\title{
Dental and periodontal health in free-ranging Swedish brown bears (Ursus arctos)
}

\author{
Anna Strömquist
}

\author{
Supervisor: Åsa Fahlman \\ Department of Pathology and Wildlife Diseases \\ National Veterinary Institute \\ 75189 Uppsala \\ Assistant supervisor: Ann Pettersson \\ Department of Clinical Sciences
}

Sveriges lantbruksuniversitet

Fakulteten för veterinärmedicin och

husdjursvetenskap

Veterinärprogrammet

Swedish University of Agricultural Sciences

Faculty of Veterinary Medicine and

Animal Science

Program of Veterinary Medicine
Examensarbete 2008:65

ISSN 1652-8697

Uppsala 2008

Degree project 2008:65

ISSN 1652-8697

Uppsala 2008

Article available at:

http://www.hihm.no/content/download/13597/121568/file/Stromquist\%20et\%20al\%20J\% 20Comp\%20Path\%202009.pdf 



\section{TABLE OF CONTENTS}

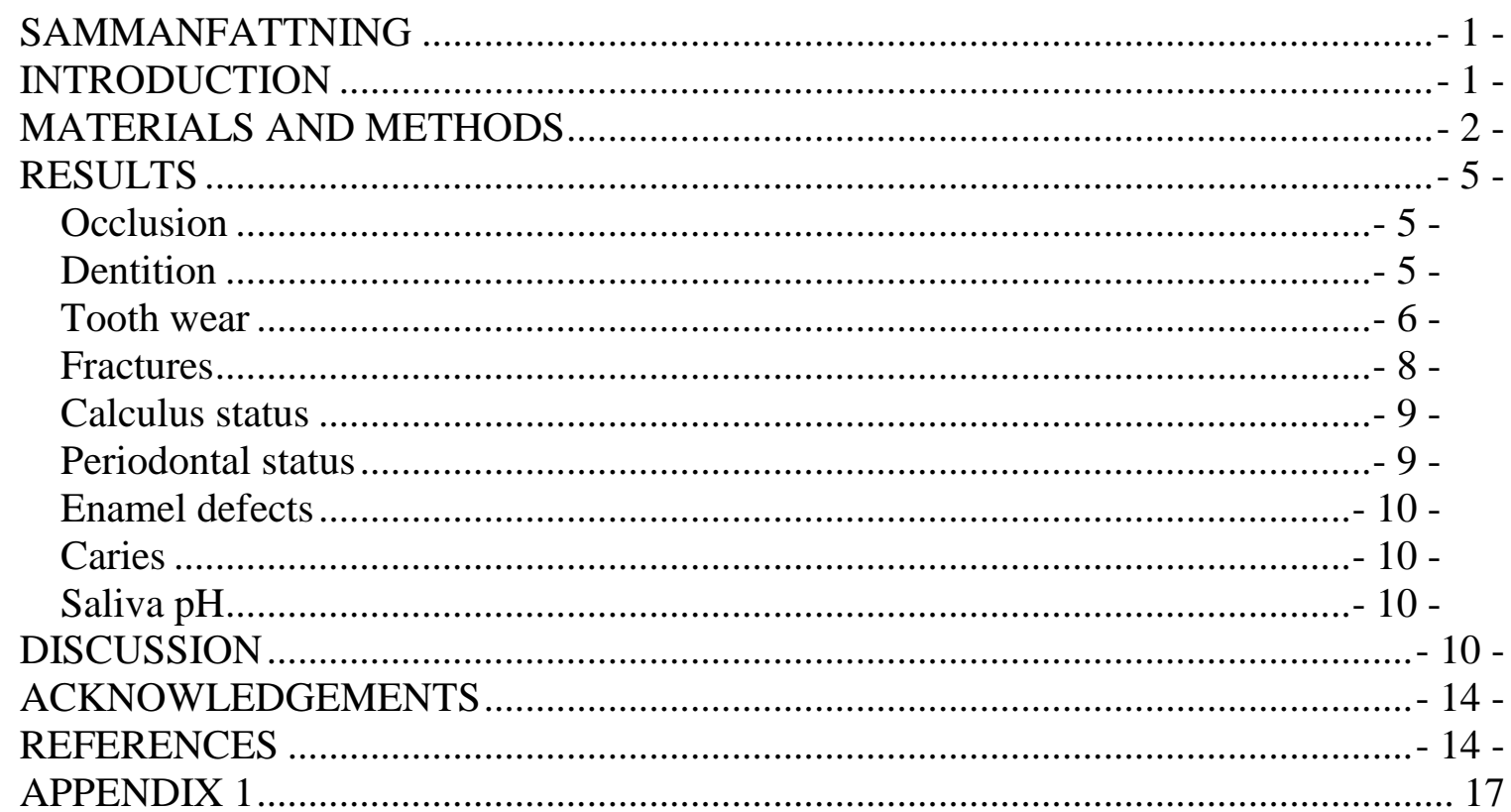





\section{SAMMANFATTNING}

Det Skandinaviska Björnprojektet har arbetat med samma björnpopulationer sedan 1984. Detta ger en unik möjlighet att över tid följa samma individer och population och därmed se eventuella förändringar som sker med dessa. Under april och maj 2008, som en del av det Skandinaviska björnprojektets årliga sövningar och märkningar av brunbjörn (Ursus arctos), undersöktes tand- och munhälsan hos 22 björnar med varierande ålder och kön. Alla björnarna vägdes och undersöktes kliniskt. Munhålan inspekterades och fotograferades. Avvikelser noterades på ett tandkort modifierat för björnar. Alla björnar var i god fysisk kondition. En björn hade lindrigt överbett som troligen var medfött. Övriga björnar hade normala bett. Fjolårsungarna visade olika stadier av eruption av den permanenta tanduppsättningen. Detta talar för att den normala tandömsningen sker mellan ett och två års ålder. Alla vuxna björnar saknade en eller flera premolarer, troligtvis på grund av arv. Tandslitage ökade med ålder och graden varierade mellan tandtyper; incisiverna var mest drabbade följt av canintänder, premolarer och molarer. Detta mönster skulle kunna förklaras av tändernas anatomiska uppbyggnad och funktion vid födointag. Tandfrakturer förekom hos åtta vuxna björnar. Frakturerna delades upp i chipfrakturer och mer omfattande frakturer. Chipfrakturer på en incisiv sågs hos fyra individer. Fyra andra individer hade mer omfattande frakturer på canintänder samt incisiver. Hos karnivorer är det oftast canintänderna som drabbas av frakturer. Detta kan förklaras av tandens form och funktion, födoval, inomarts- samt predator/bytesdjurs-interaktioner. Ingen eller låg frekvens av tandsten och tecken på parodontit sågs hos de undersökta björnarna. Detta kan bero på att födan har en förebyggande sammansättning samt en självrengörande effekt på tänderna. Medelvärdet på pH i saliven var 9.75. Det kan vara en förklaring till att ingen björn hade karies. En mycket intressant upptäckt var att alla vuxna björna utom en, samt en fjolårsunge, uppvisade skador i emaljen som på många sätt liknar emaljhypoplasi. Orsaken till detta är okänd, men kan bero på genetiska förutsättningar och/eller faktorer i omgivningen som ger upphov till metabolisk stress. Ytterligare studier, som skulle innefatta ett större antal individer och olika geografiskt och genetiskt skilda populationer, skulle kunna ge mer information om samt förklaringar till avsaknaden av premolarer, den låga förekomsten av tandsten, parodontit och karies, samt den stora andelen emaljhypoplasi-liknande skador.

\section{INTRODUCTION}

Pathology of the oral cavity frequently occurs in domestic as well as in wild animals (Cuozzo et Sauther, 2006; Hungerford et al, 1999; Wenker et al., 1999). However, dental and periodontal studies of wild animals are limited (Hungerford et al., 1999; Robinson, 1979).

Dental abnormalities may be of congenital origin, for example malocclusion, supernumerary teeth or hypodontia (Miles et Grigson, 1990). This can lead to abnormal mechanical wear (Harvey et Orr, 1990). These types of lesions can also be acquired by factors such as trauma. Fractures or fissures of the teeth, caused by trauma, can affect an animal in every stage of life (Malzoni Furtado et al., 2007; 
Lobprise, 2003; Sauther et al., 2002; Harvey et Orr, 1990). Several studies have shown a high prevalence of tooth fractures in wild animals (Malzoni Furtado et al., 2007; Abbot et Verstraete, 2005; Sauther et al., 2002). Attrition is the wear of one tooth moving against another or the wear of teeth against food during mastication (Miles et Grigson, 1990). Dental attrition progresses over time and thus increases with age (Cuozzo et Sauther, 2006; Wenker et al., 1999). Therefore, attrition may be used as a measure of relative age (Sauther et al., 2002).

Infectious agents can cause dental and periodontal lesions, often combined with other factors such as abnormal tooth positions, structural tooth defects and improper diet (Harvey et Orr, 1990). Periodontitis is caused by plaque and is the most common oral disease seen in small animal practice (Gorrel, 2004). Roughly, $85 \%$ of all cats and dogs older than two years are affected by periodontal disease in some stage. (Harvey et Orr, 1990). Periodontitis per definition is an inflammation of the periodontium which include the gingiva, cementum, alveolar bone, and the periodontal ligament (figure 1). Periodontal disease embraces everything from mild reversible gingivitis to severe tooth loss (Gorrel, 2004; Harvey et Orr, 1990). Caries is another dental disease caused by the activity of microorganisms. It is a progressive demineralization and destruction of enamel, dentine or cementum (Gorrel, 2004).

As part of the Scandinavian Bear Project, freeranging brown bears (Ursus arctos) have been

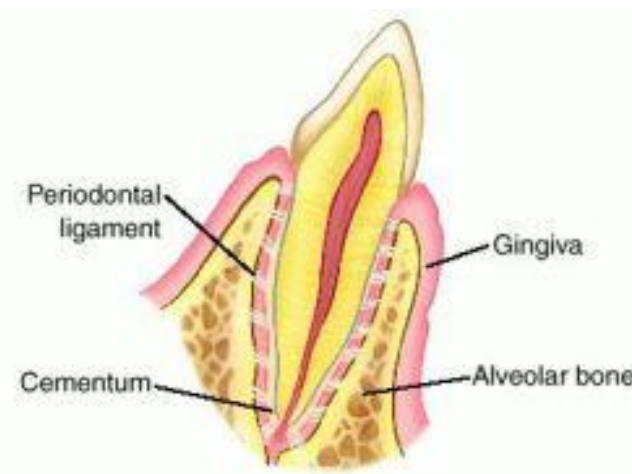

Figure 1. Diagrammatic section of a tooth showing the structures of the periodontium. Modified from: http://img.tfd.com/dorland/thumbs/peri odontium.jpg captured since 1984. During anesthesia, the bears have been radio marked and biological samples have been collected for demographic, genetic and ecological studies. During the captures, lesions on bear teeth have been noted but no further studies have been made.

The aim of this study was to evaluate the dental and periodontal status of free-ranging brown bears in Sweden.

\section{MATERIALS AND METHODS}

During April and May of 2008, as a part of the Scandinavian Bear Project's annual captures of free-ranging brown bears, dental data was collected from 22 bears. All captures took place in the county of Dalarna, Sweden (figure 2). Approval was given by the Ethical Committee on Animal Experiments in Uppsala, Sweden.

The animals were immobilized from a helicopter using a remote drug delivery system (Dan-Inject ${ }^{\circledR}$, B $\varnothing$ rkop, Danmark). For yearlings, $1.5 \mathrm{ml}$ darts with $1.5 \times 25 \mathrm{~mm}$ barbed needles were used. For adults, $3 \mathrm{ml}$ darts with $2.0 \times 40 \mathrm{~mm}$ barbed needles were used. The bears were immobilized with tiletamin-zolazepam (Zoletil forte vet ${ }^{\circledR}$. Virbac S.A., Cedex, France) in combination with medetomidine (Domitor® vet. $1 \mathrm{mg} / \mathrm{ml}$ or 
Zalopine ${ }^{\circledR}, 10 \mathrm{mg} / \mathrm{ml}$, Orion Pharma Animal Health, Espoo, Finland) at standard drug doses according to body size (Arnemo and Fahlman, 2008). The total time of anesthesia was approximately 60 minutes. The time allowed for oral examination was further limited to 15 minutes.

The bears were divided into yearlings (one to two years old) and adults. Seven of the bears were yearlings; one female and six males. Fifteen of the captured animals were adults; ten females and five males. The age of 12 adults were known due to earlier captures and varied from four to 18 years. These individuals had been known since they were yearlings or, determination of age had been made based on cementum annuli in one premolar extracted during capture (Matson, 1981). In the remaining three bears, age was estimated to be less than ten years based on tooth wear.

All animals were weighed and physically examined. The oral examinations were made by two persons. To achieve the same references, these persons examined the six first bears together. The oral cavity was inspected and photographed. Abnormalities were recorded on a dental chart modified for bears (appendix 1). Teeth were counted, and occlusion status was documented. To assess oral health, four measurements were used; calculi index (CI), gingival index (GI), periodontal index (PDI) (Kesel, 2000), and tooth wear (TW) (Hungerford et al., 1999), adapted to field conditions (table 1).

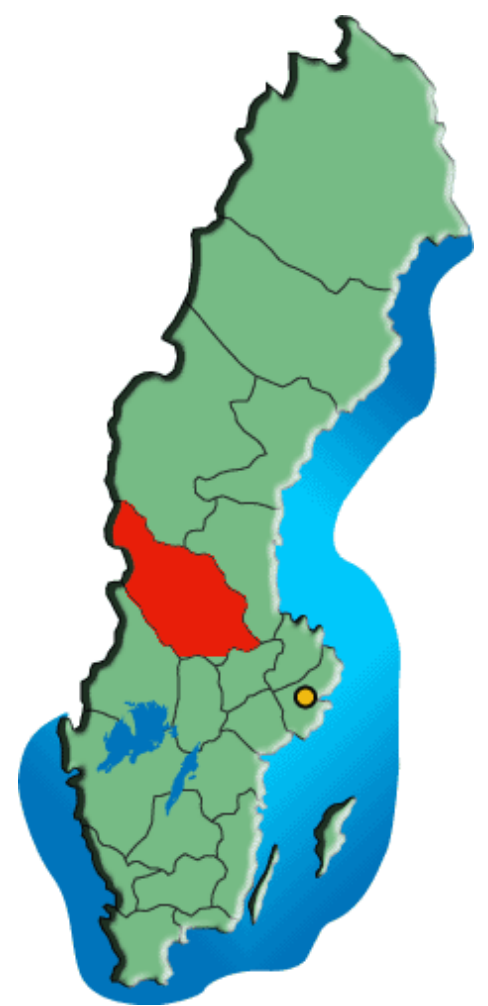

Figure 2. Map of Sweden, the county of Dalarna is red marked.

(www.buscainmobiliarias.com/se/mapas/dalarna.gif). 
Table 1. Measures used to evaluate dental health in brown bears

\begin{tabular}{|c|c|c|}
\hline \multirow{2}{*}{$\begin{array}{l}\text { Measure } \\
\text { Calculi }\end{array}$} & \multicolumn{2}{|c|}{ Scales and identifications } \\
\hline & CI $0=$ & No calculi present. \\
\hline \multirow[t]{3}{*}{$(\mathrm{CI})$} & $\mathrm{CI} 1=$ & $\begin{array}{l}\text { Presence of calculi covering }<50 \% \text { of the } \\
\text { tooth crowns. }\end{array}$ \\
\hline & CI $2=$ & $\begin{array}{l}\text { Presence of calculi covering }>50 \% \text { but not } \\
100 \% \text { of the tooth crowns. }\end{array}$ \\
\hline & CI $3=$ & $\begin{array}{l}\text { Presence of calculi covering } 100 \% \text { of the } \\
\text { tooth crowns. }\end{array}$ \\
\hline \multirow{4}{*}{$\begin{array}{l}\text { Gingival index } \\
\text { (GI) }\end{array}$} & GI $0=$ & Normal, no swelling. \\
\hline & GI $1=$ & $\begin{array}{l}<50 \% \text { of the gingiva has swollen, rounded } \\
\text { or reddening margins. }\end{array}$ \\
\hline & GI $2=$ & $\begin{array}{l}>50 \% \text { of the gingiva has swollen, rounded } \\
\text { or reddening margins, bleeding appears } \\
\text { after passing a periodontal probe gently } \\
\text { along the sulcus. }\end{array}$ \\
\hline & GI $3=$ & $\begin{array}{l}\text { GI 2, gingival hyperplasia, ulcers and/or } \\
\text { spontaneous bleeding. }\end{array}$ \\
\hline \multirow{4}{*}{$\begin{array}{l}\text { Periodontal } \\
\text { index (PDI) }\end{array}$} & PDI $1=$ & GI 1 \\
\hline & PDI $2=$ & $\begin{array}{l}\text { GI } 1-2 \text {, minimal gingival recession and/or } \\
\text { shallow pocket formation in }<25 \% \text { of the } \\
\text { teeth. }\end{array}$ \\
\hline & PDI $3=$ & $\begin{array}{l}\text { GI } 1-3 \text {, hyperplasia or pus, gingival } \\
\text { recession and pocket formation in }>25 \% \\
\text { of the teeth, imminent loss of teeth. }\end{array}$ \\
\hline & PDI $4=$ & $\begin{array}{l}\text { GI 2-3, appearance of pus and spontaneous } \\
\text { teeth loss. }\end{array}$ \\
\hline \multirow[t]{4}{*}{ Tooth wear } & TW $0=$ & No wear. \\
\hline & TW $1=$ & Mild blunting of teeth profile. \\
\hline & TW $2=$ & $\begin{array}{l}\text { Moderate wear of incisors and canines, } \\
\text { crest of molars still evident. }\end{array}$ \\
\hline & TW $3=$ & $\begin{array}{l}\text { Appearance of teeth worn to the margin of } \\
\text { the gingiva. }\end{array}$ \\
\hline
\end{tabular}

Lesions of the teeth such as fractures, presence of enamel defects and dental caries were also noted. Caries was defined as a discoloration of the tooth surface into which a dental explorer could be inserted and offer a slight resistance when removed (Sauther et al., 2002; Harvey et Orr, 1990). Periodontal pocket depth was measured around all teeth with a dental probe and depths exceeding $4 \mathrm{~mm}$ were noted (figure 3). $\mathrm{PH}$ in the saliva was recorded using $\mathrm{pH}$ strips, $(\mathrm{pH}$ 0-14 Universalindikator, Merck, Germany).

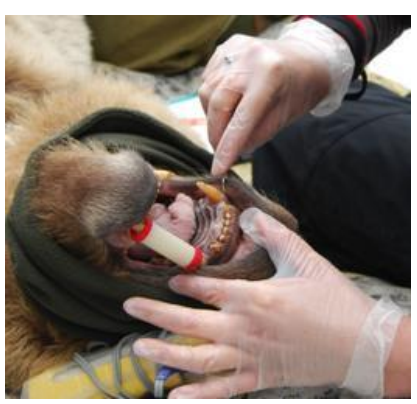

Figure 3. Periodontal pocket depth is measured with a dental probe. 


\section{RESULTS}

All captured animals were presented in good physical condition.

\section{Occlusion}

Mild class II malocclusion (distocclusion) (Wiggs et Lobprise, 1997) was found in one adult male bear (figure $4 \mathrm{a}$ and $4 \mathrm{~b}$ ). Due to interlocking of the canines, the animal was unable to close its mouth in a normal position. Enamel was missing due to abnormal attrition on the contact sites of the canines. No malocclusion was found in the other 21 bears (figure 5).

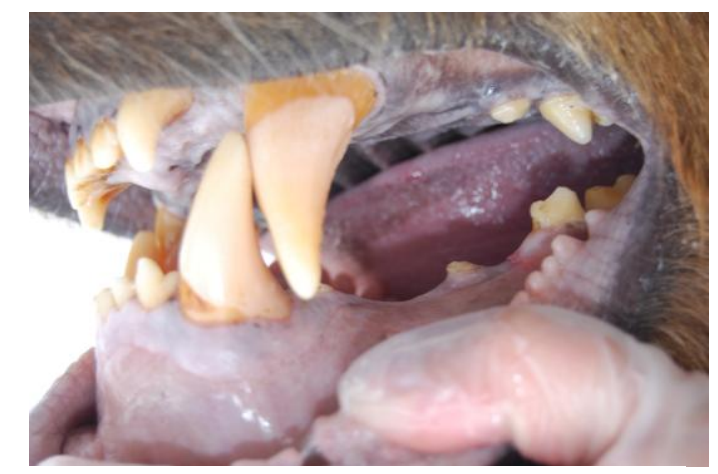

Figure 4a. Adult male with class II malocclusion. The mouth cannot close in normal position.

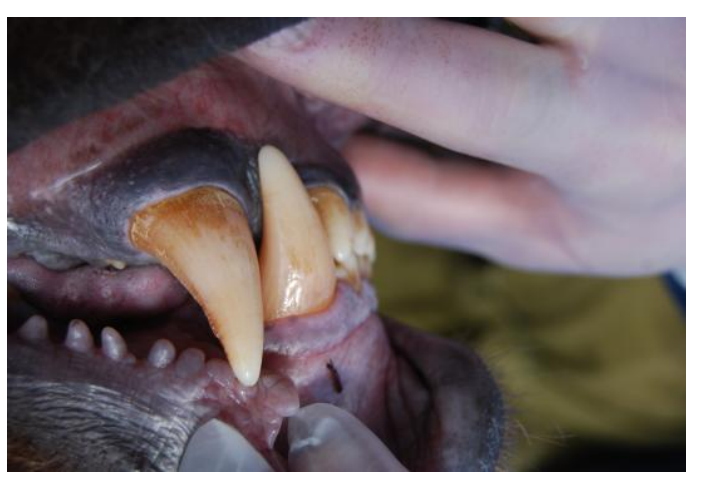

Figure 5. Adult male with no malocclusion. The mouth is completely closed.

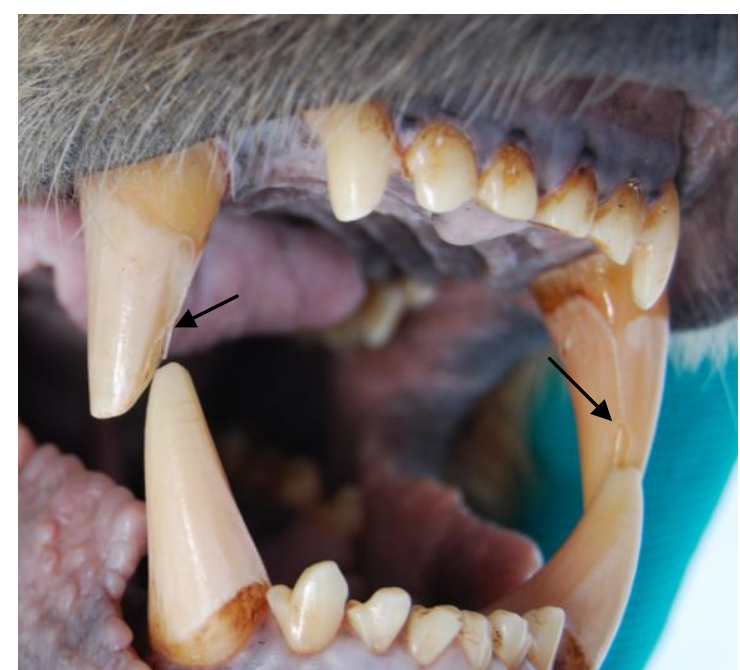

Figure 4b. Adult male with class II malocclusion. Arrows show attrition on contact sites of canines.

\section{Dentition}

All yearlings showed various stages of incomplete eruption of permanent teeth and were, due to this, missing different numbers of teeth. In most yearlings, one or more canines were missing. 
Thirteen adult bears were missing one premolar due to previous extraction for age determination. Even when taking this in account, all animals had an incomplete dentition with various numbers of missing premolars (table 2, figure 6). One 18 year old female was missing the right upper incisor 1 .

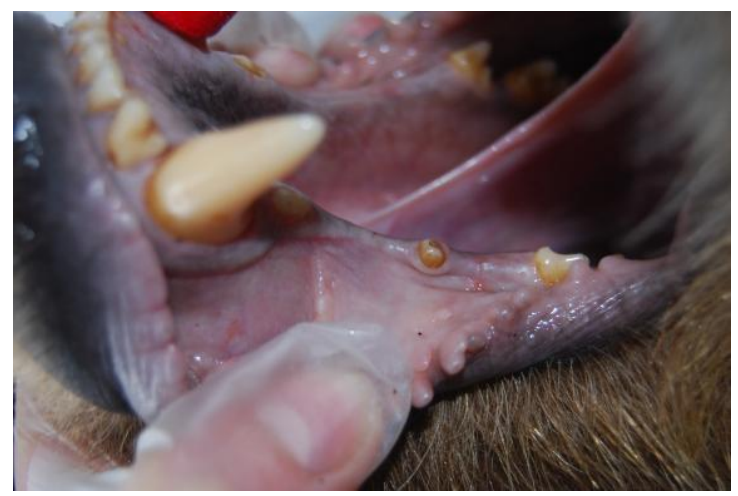

Figure 6. Adult female, missing lower P2 and $P 3(d x)$, and $P 2(\sin )$.

Table 2. Number of missing premolars in relation to age (* one of the missing premolars had been extracted during previous captures).

\begin{tabular}{ll}
\hline Age (years) & Nr of missing \\
& premolars \\
4 & 1 \\
5 & 7 \\
7 & $6 *$ \\
8 & $6 *$ \\
9 & $5 *$ \\
$<10$ & $6 *$ \\
$<10$ & $6 *$ \\
$<10$ & $8 *$ \\
10 & $6 *$ \\
11 & $6 *$ \\
13 & $4 *$ \\
15 & $6 *$ \\
16 & $7 *$ \\
16 & $6 *$ \\
18 & $7 *$ \\
\hline
\end{tabular}

\section{Tooth wear}

Tooth wear increased with age and was only documented in adults. Tooth wear in relation to age and gender of adult bears is shown in table 3. Eight bears (four females and four males, age ranging from four to ten years) had TW 1. One sevenyear old and one 11 years old female had TW 2. Five female bears in the age of 13 to 18 years old had TW 3.

In bears with TW 1, the only teeth affected were the incisors, most frequently the maxillary incisors (figure 7). In higher index numbers of tooth wear, the wear of the 
incisors was more severe (figure 8a,b). Additionally, wear of canines and occlusal surfaces of premolars and molars was also noted

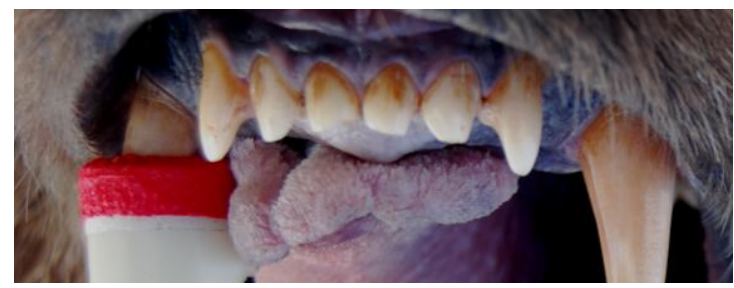

Figure 7. Male, <10 years, TW 1.

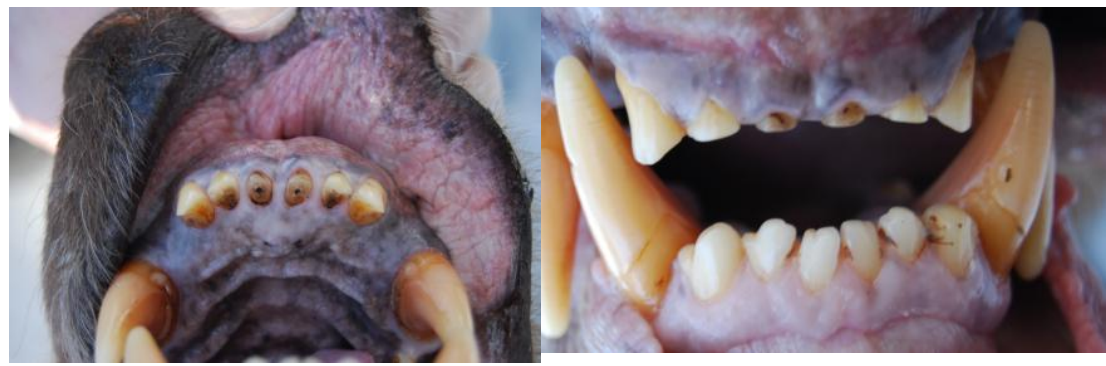

Figure 8a,b. Female, 13 years, TW 3 in upper incisors.

Table 3. Distribution of age, gender and tooth wear of the adult bears.

\begin{tabular}{lll}
\hline Age (years) & Gender & Tooth wear \\
4 & F & 1 \\
5 & F & 1 \\
8 & F & 1 \\
9 & F & 1 \\
$<10$ & M & 1 \\
$<10$ & M & 1 \\
$<10$ & M & 1 \\
10 & M & 1 \\
7 & F & 2 \\
11 & F & 2 \\
13 & F & 3 \\
15 & F & 3 \\
16 & F & 3 \\
16 & M & 3 \\
18 & F & 3 \\
\hline
\end{tabular}




\section{Fractures}

Obvious fractures were found in eight adult animals. Four bears had chip fractures of one incisor (figure 9). Other fractures were more severe and included canines and/or incisors (figure 10). No attempt was made to classify the fracture-types further.

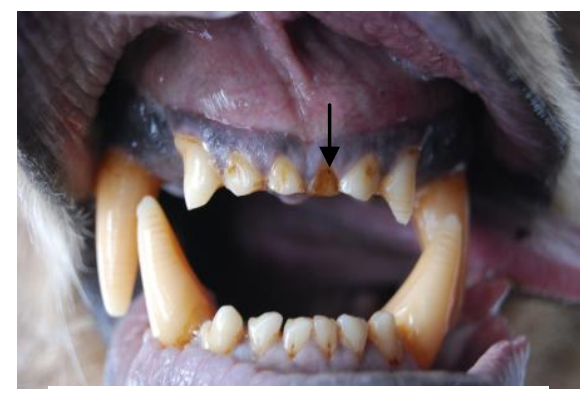

Figure 9. Female, seven years, chip fracture upper II $\sin ($ arrow).

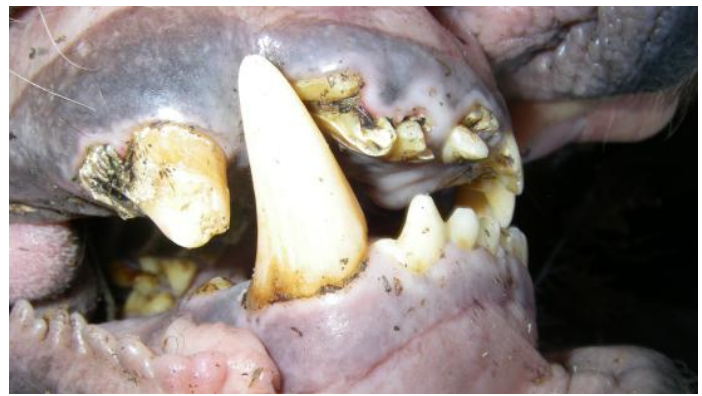

Figure 10. Female, eight years, severe fractures of upper C1, I1,2,3 dx.

In two bears, tooth remnants of incisors were found and one bear had only remnants of both upper P4 (figure 11). The cause of the tooth remnants is unknown. The distribution of fractures and tooth remnants in relation to age and gender is found in table 4.

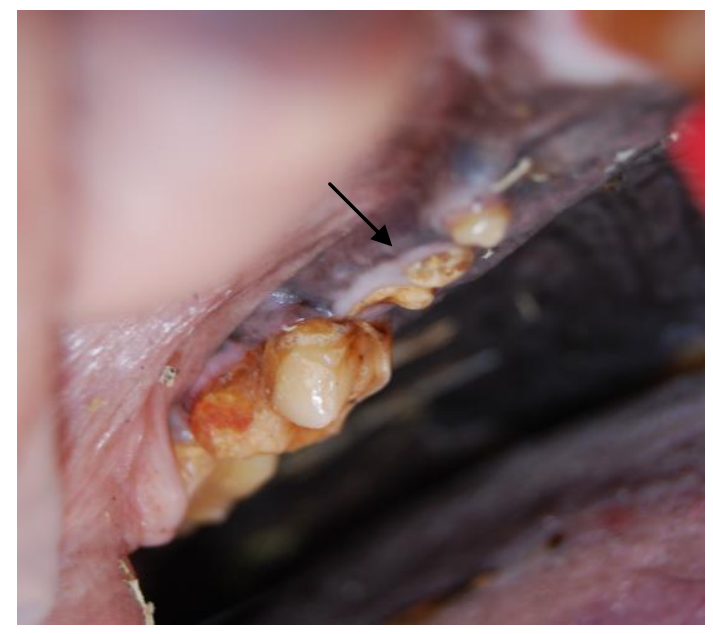

Figure 11. Female, 16 years, remnants of upper $\mathrm{P} 4 \mathrm{sin}$ (arrow). 
Table 4. Distribution of fractures and tooth remnants in relation to age and gender

\begin{tabular}{|c|c|c|c|}
\hline Age (years) & Gender & Fractured tooth & Tooth remnants \\
\hline 4 & $\mathrm{~F}$ & Lower I1 sin (chip) & - \\
\hline 7 & $\mathrm{~F}$ & Upper I1 sin (chip) & - \\
\hline 8 & $\mathrm{~F}$ & $\begin{array}{l}\text { Upper } \mathrm{C} 1 \mathrm{dx} \\
\text { Upper I1,2,3 dx }\end{array}$ & - \\
\hline$<10$ & M & Lower I1 sin (chip) & - \\
\hline 10 & M & Upper I2 dx (chip) & - \\
\hline 15 & $\mathrm{~F}$ & Lower $\mathrm{C} 1 \mathrm{dx}$ & - \\
\hline 16 & $\mathrm{~F}$ & & Upper P4 sin/dx \\
\hline 16 & M & $\begin{array}{l}\text { Upper and lower } \mathrm{C} 1 \mathrm{dx} \text {, upper } \mathrm{I} 3 \\
\mathrm{dx} \text {, lower } \mathrm{C} 1 \sin \end{array}$ & Lower I1,2,3 sin \\
\hline 18 & $\mathrm{~F}$ & Lower $\mathrm{C} 1 \mathrm{dx}$, lower $\mathrm{I} 3 \mathrm{dx}$ & Lower I1 sin, upper I $2 \mathrm{dx}$ \\
\hline
\end{tabular}

\section{Calculus status}

Calculus was not found in any of the yearlings. Ten adult bears had CI 1 and one had CI 2, although, all teeth were not affected. The predominant location of dental calculus was on molars and P4 (figure 12).

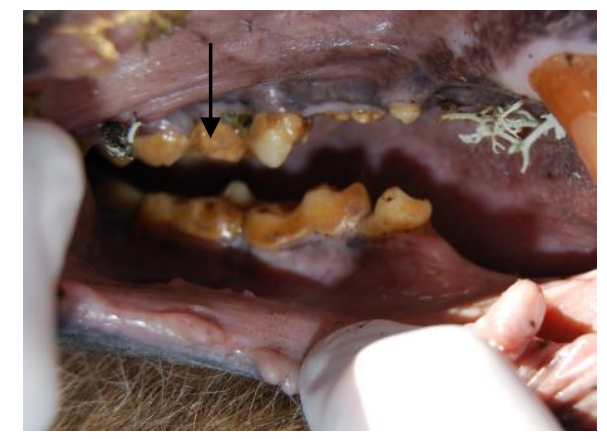

Figure 12. 16 year old female with CI 2 (arrow).

\section{Periodontal status}

All yearlings and six of the adults did not show any signs of periodontal disease. Mild gingivitis (PDI 1) was present in six adults and three had PDI 2. 


\section{Enamel defects}

Macroscopic lesions resembling enamel hypoplasia were found in all adults except one (figure 13 and 14), and in one yearling. The lesions were characterized by irregular pits or a band-shaped absence of enamel. In all affected bears, enamel hypoplasia-like defects were evident in the canines. In six adults, the incisors were further affected. The entire erupted permanent dentition was affected in the yearling.

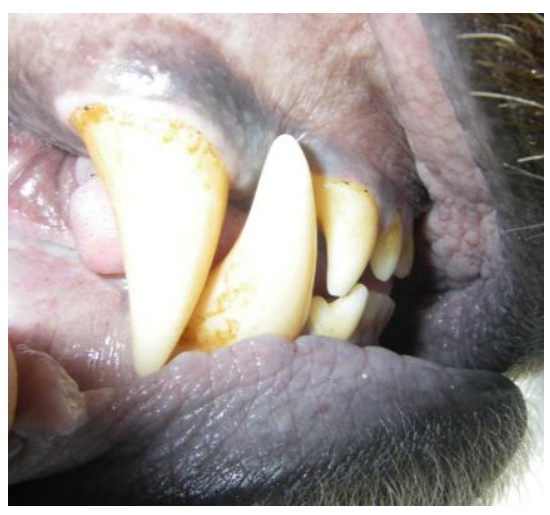

Figure 13. Five year old female, no macroscopic evidence of enamel hypoplasia.

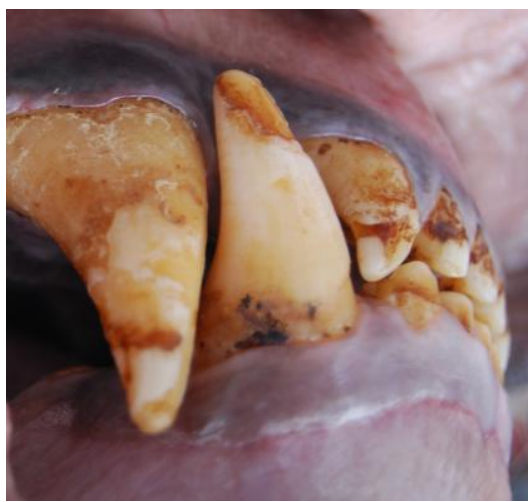

Figure 14. Four year old female, canines and incisors affected by enamel hypoplasia like defects.

\section{Caries}

No obvious case of caries, according to the present definition, was found.

\section{Saliva $\mathrm{pH}$}

The $\mathrm{pH}$ in the saliva was measured in 16 bears. Four bears had $\mathrm{pH} 9$ and 12 bears had $\mathrm{pH} 10$ (mean $\mathrm{pH} 9.75$ ) in the saliva.

\section{DISCUSSION}

The Scandinavian Bear Project has been working with the same population of bears since 1984. This gives excellent means by which changes over time in individuals as well as in the whole population can be monitored. This was the first study of dental and periodontal health in this population. Further studies of the Scandinavian bears would provide a unique opportunity to investigate the development of oral health in free-ranging bears. Moreover, there are several parameters that need to be collected from a living animal such as bleeding index, presence of gingivitis and saliva $\mathrm{pH}$. However, there are limitations when examining animals under field conditions compared to in a clinic. Due to time restraint, index numbers (CI, PDI, TW) were set to the entire mouth instead of to individual teeth which would have been preferable since the index numbers may differ among teeth. No portable dental radiograph was 
available in this study. Consequently, some findings, such as hypodontia, root fractures, periodontal disease, caries and neoplasias could be missed. However, strength of the present study was that the examined bears were alive since when examining prepared skulls, loss of teeth during preparation and handling is a considerable risk, and may affect the study results. When examining hunter-harvested bears or bears killed in traffic, the skull may be traumatized and teeth may be broken or lost which complicates the examination.

Since the examined number of animals was relatively low, preference was taken to discuss individuals instead of prevalence or percentage. Further due to low sample size, conclusions regarding gender are excluded.

The mild class II malocclusion (overshot bite) found in only one adult male may be caused by inheritance since this is thought to be the primary cause of this type of malocclusion (Harvey and Emily, 1993). Though, the precise role of heredity as etiologic agent for malocclusion has not been clarified. Malocclusion can also be the result of trauma or slowed growth due to illness during a period of normal jaw development. (Harvey and Emily, 1993). Wenker et al. (1999) examined 63 skulls of captive brown bears and 14 skulls from free-ranging Alaskan brown bears, (Ursus arctos horribilis). They found that six of the captive brown bears had mild mandibular prognathia (undershot bite). However, a hereditary cause could not be determined. One of the captive bears showed severe right lateral nonocclusion. The deformity must have been well compensated for since the bear died at an age of 27 years. None of the free-ranging bears, in that study, showed malocclusion.

The normal dental eruption pattern for the Scandinavian brown bear has, to the authors' knowledge, not been determined. However, the results of this study indicate that eruption of the permanent dentition occurs between one and two years of age. Knowledge of eruption time of both deciduous and permanent teeth is important, since the overlapping of these two sequences of events can be a cause of dental problems (Robinson, 1979).

The normal dental formula for bears, family Ursidae, is:

$$
\frac{3}{3} \quad \frac{1}{1} \quad \frac{4}{4} \quad \frac{3}{2} \quad=42 \text { teeth. }
$$

In the present study, all brown bears were, based on ocular examination and palpation over the gingiva, missing one or more premolars. The cause of this is unknown and by macroscopic observation, differentiation between hypodontia (congenital absence of one or more teeth), failure to erupt, and tooth loss for other reasons can not be made. For this, radiological examination may be used. Tooth loss could result from trauma, extraction, and periodontitis. According to the healthy periodontal status of the examined bears, it is unlikely that periodontal disease had caused tooth loss. In the examined population, a congenital factor, resulting in hypodontia or failure to erupt, is most likely the cause of the missing premolars. Data from an earlier study showed a similar pattern in American black bears (Ursus americanus). Only $2 \%$ of 
159 examined skulls in that study had full complement of premolars. Since there was no difference in dental loss according to age, it was concluded that the absence was congenital. (Miles et Grigson, 1990). However, Wenker et al. (1998) found that all examined captive brown bears $(n=5)$, had a complete set of 42 teeth. In small domestic animals with hypodontia, the premolars are most often missing, and one cause of this condition is an autosomal recessive genetic abnormality (Harvey et Orr, 1990).

Tooth wear increased with age which is in accordance to previous studies (Cuozzo et Sauther, 2006; Wenker et al., 1999).The most affected teeth were the incisors followed by canines, molars and premolars. Wenker et al. (1999) found a comparable pattern. This was explained by the different thickness, structure, and target of enamel and dentin in these locations. Sonne et al. (2007) studied skulls of polar bears (Ursus maritimus) and found that tooth wear was more severe in the incisors than in other teeth. They indicate that the cause of this might be the feeding habits of the polar bears. Polar bears use their incisors to tear off muscles from carcasses, therefore, causing wear on the teeth. It is likely that brown bears use their incisors in the same way leading to a similar tooth wear. Probably, the cause of the wearing distribution among teeth is a combination of anatomical characteristics and function of different teeth.

Root fractures may have been missed since radiography was not used. The severe fractures, found in the present study, were most common in the canines. In carnivores, the canines are, compared to other teeth, most susceptible to injure. (Malzoni Furtado et al., 2007; van Valkenburgh, 1988). Morphological and anatomical characteristics of the teeth, as well as diet and behavior habits, may predispose certain teeth to injure. The canine teeth, due to their shape and function, enhance further bending moments compared to other teeth. The canines are long relative to their base and are used while killing prey. Biting into a prey causes bending stress across the tooth. Moreover, while the canines are driven into a prey, redirections of the bite, to prevent large bending moments caused by the struggle of the prey, is difficult. (van Valkenburgh, 1988). In addition, animal interaction and aggression may also cause this pattern of tooth breakage (Verstaete et al., 1996). It is probably combinations of shape and function of teeth, diet, intraspecies interactions as well as predator-prey interactions that have caused the distribution of fractures in the examined bears.

The causes of the remnants of teeth, found in three bears, are unknown. Possible etiology may be old fractures due to external trauma, severe caries or abnormal tooth wear. Although, caries is a less probable cause since this was not documented in any of the examined bears.

Calculus was not a common finding in the examined bears. Wenker et al. (1999) found that captive bears had higher prevalence of calculus than free-ranging bears, which probably was due to inappropriate diet and the lack of tooth-cleaning activities in captivity. This would lead to plaque deposits and calculus formation. The diet of Scandinavian brown bears consists of ungulates, i.e. moose calves (Alces alces) and 
ants during the spring, mostly forbs during the summer and berries in the autumn (Dahle et al., 1998). The relatively low prevalence of calculus found in this study indicates that the diet is nutritionally appropriate and has a self-cleaning effect on the teeth. The bear with CI 2 was a female, aged 16 years and in addition to calculus, it had only remnants of both upper P4. The cause of this could be fractures due to trauma. Fractures can affect the development of calculus since the animals might avoid chewing nearby the locations of the fracture.

The examined bears showed little or no signs of periodontal disease. Manville (1992) found that prevalence of periodontal disease differed between study areas. In Wisconsin, one of 95 bears was affected as compared to 13 out of 35 bears in Michigan. The cause of this difference was not discussed. Perhaps prevalence of periodontal disease differs between populations in Scandinavia as well. Further studies, including different cohorts, will give more information and may help to explain the pattern.

Fifteen animals had macroscopic lesions resembling enamel hypoplasia. No such data from earlier studies have been found.

No obvious case of caries, according to the present definition, was found. Manville (1992) defined caries as an area where the enamel and dentine were broken down or disintegrated. By this definition, a caries prevalence of $10.5 \%(\mathrm{n}=86$, Wisconsin) and $20 \%(\mathrm{n}=35$, Michigan) was found in black bears (Manville, 1992). On the other hand, Hall (1940) found a relatively low prevalence in black bears $(3 \%, n=195)$ and grizzly bears $(2 \%, \mathrm{n}=165)$. The caries probably developed due to a carbohydrate rich diet of berries and honey. Honey was not included in the diet of the examined bears in the present study. Caries is caused by bacteria in the plaque surrounding the teeth. The bacteria produce acid when metabolizing carbohydrates (Gorrel, 2004) and are thereby said to be acidogenic (Featherstone, 2000). The acids lower the $\mathrm{pH}$ in the plaque, and with a lower $\mathrm{pH}$, the acids diffuse more rapidly into the enamel and dentin (Featherstone, 2000). This causes a demineralization of the enamel and dentin by dissolving the calcium phosphate mineral of the tooth. If not halted, the process will lead to at cavity in the tooth. (Gorrel, 2004; Featherstone, 2000). The saliva contains buffers which resist pH changes (Dawes, 2008; Dowd, 1999; Peretz et al., 1990). The alkaline $\mathrm{pH}$ (mean 9.75) found in the present study may be one explanation to the low frequency of caries.

Little is known about dental and periodontal health in free-ranging wildlife. Investigations about dental status tell us, in addition to pathology, in a wider perspective, more about the behavior and feeding habits of an animal population. By applying knowledge of the dental and periodontal health of free-ranging animals to pets and wild animals in captivity, one might prevent some oral disturbances. The examined bears showed little or no calculus, periodontal disease or caries infections. All three conditions are common in dogs, cats and some zoo animals. By changing diet to a more natural composition and structure and by introducing materials and challenges that are found in the natural habitat of the animal, one might reduce such conditions. Teeth fractures and severe tooth wear with additional pulp infections 
appear in both wildlife and captive animals. Even though these conditions naturally occur in the wild, such lesions must be treated when found in captive animal, to minimize the suffering of the animal. The high frequency of enamel hypoplasia like lesions in the examined bears was surprising and further studies of the cause and geographical distribution should be made.

\section{ACKNOWLEDGEMENTS}

I would like to thank my supervisor Dr Åsa Fahlman for introducing me to the Scandinavian Bear Project, and my assistant supervisor Dr Ann Pettersson for her never ending enthusiasm and commitment to this study. I am most grateful to the Scandinavian Bear Project, especially Sven Brunberg, for including me in their project. This study would never have been done without their support. Thanks to Michelle Oakley for assistance in collecting data. I would also like to thank Olavi Grönwall and Peter Mortensen at the Swedish Museum of Natural History in Stockholm for sharing their valuable material.

\section{REFERENCES}

Abbot, C. and Verstraete, F.J.M. 2005. The dental pathology of northern elephant seals (Mirounga angustirostris). Journal of Comparative Pathology 132, 169-178.

Arnemo, J.M. and Fahlman, Å. 2008. Biomedical protocols for free-ranging brown bears, grey wolves, wolverines and lynx.

http://www.rovviltportalen.no/content.ap?thisId=500026811 2008-04-23.

Bhaskar, S.N. 1977. Synopsis of oral pathology, 5:th ed. Saint Louis: Mosby. 115pp.

Bittegeko, S.B.P.R., Arnbjerg, J., Nkya, R. and Tevik, A. 1995. Multiple dental developmental abnormalities following canine distemper infection. Journal of the American Animal Hospital Association, 1:31, 42-45.

Cuozzo, F.P. and Sauther, M.L. 2006. Severe wear and tooth loss in wild ring tailed lemurs (Lemur catta): A function of feeding ecology, dental structure, and individual life story. Journal of Human Evolution 51, 490-505.

Dahle, B., Sørensen, O.J., Wedul, E.H., Swensson, J.E. and Sandegren, F. 1998. The diet of brown bears Ursus arctos in central Scandinavia: effect of access to free-ranging domestic sheep Ovis aries. Wildlife Biology 4:3, 147-158.

Dawes, C. 2008. Salivary flow patterns and the health of hard and soft oral tissues. Journal of American Dental Association 139:2, 18-24.

Dowd, F.J. 1999. Saliva and dental caries. Dental clinics of North America 43:4, 579-597.

Featherstone, J.D.B. 2000. The science and practice of caries prevention. The Journal of the American dental association 131, 887-899. 
Goodman, A.H. and Armelagos, G.J. 1985. Factors affecting the distribution of enamel hypoplasias within the human dentition. American Journal of Physical Anthropology 68, 479-493.

Gorrel, C. 2004. Veterinary dentistry for the general practitioner. Saunders, Philadelphia. 31, 76-77, 87-88pp.

Guatelli-Steinberg, D. 2000. Linear enamel hypoplasia in gibbons (Hylobates lar carpenteri). American Journal of Physical Anthropology 112, 395-410.

Guatelli-Steinberg, D. and Skinner, M. 2000. Prevalence and etiology of linear enamel hypoplasia in monkeys and apes from Asia and Africa. Folia Primatologica 71, 115 $-132$.

Hall, E.R. 1940. Supernumerary and missing teeth in wild animals of the orders insectivore and carnivora, with some notes on disease. Journal of Dental Research 19, 103-143.

Harvey, C.E. and Orr, H.S. 1990. Manual of Small Animal Dentistry. West Sussex: KCU, Worthing. 37, 85pp.

Harvey, C.E. and Emily, P.P. 1993. Small animal dentistry. St Louis: Mosby -Year Book inc. 270-272 pp.

Hillson, S. and Bond, S. 1997. Relationship of enamel hypoplasia to the pattern of tooth crown growth: A discussion. American Journal of Physical Anthropology 104, 89103.

Hungerford, L.L., Mitchell, M.A., Nixon, C.M., Esker, T.E., Sullivan, J.B., Koerkenmeier, R. and Manfra Maretta, S. 1999. Periodontal and dental lesions in raccoons from a farming and a recreational area in Illinois. Journal of Wildlife Diseases 35:4, 728734.

Kesel, M.L. 2000. Veterinary Dentistry for the Small Animal Technician, 1 ed. Iowa: Iowa State University Press. 121-136pp.

Lobprise, H.B. 2003. Puppy and kitten dental care. Recent Advances in Dental Health Management: Presented at the $8^{\text {th }}$ World Veterinary Congress. Dayton: The Iams Company. 33-36pp.

Malzoni Furtado, M., Kashivakura, C.K., Ferro, C., de Almeida Jácomo, A.T., Silveira, L., Astete, S. and Lopes, F.M. 2007. Prevalence of crown trauma in free-ranging maned wolves (Chrysocyon brachyurus) in central Brazil. Journal of Veterinary Dentistry 24:4, 231-234.

Manville, A. 1992. Variability of dental disease in two populations of Great Lake black bears. International Conference on Bear Research and Management 8, 129-134.

Matson, G.M. 1981. Workbook for cementum analysis. http://www.matsonslab.com/html/Miscellaneous/Publications/Workbook\%20for\%2 0Cementum\%20Analysis.pdf 2008-05-05. 
Miles, A.E.W. and Grigson, C. 1990. Colyer's Variations and diseases of the teeth of animals, rev. ed. Avon: Cambridge University Press. 77, 437-438pp.

Moggi-Cecchi, J. and Crovella, S. 1991. Occurrence of enamel hypoplasia in the dentitions of Simian primates. Folia Primatologica 57, 106-110.

Nunn, J.H., Rugg-Gunn, A.J., Ekanayake, L. and Saparamadu, K.D.G. 1994. Prevalence of developmental defects of enamel in areas with differing water fluoride levels and socio-economic groups in Sri Lanka and England. International Dental Journal 44, 165-173.

Peretz, B., Sarnat, H. and Moss, S.J.1990. Caries protective aspects of saliva and enamel. NYS Dental Journal 1, 25-27.

Robinson, P.T. 1979. A literature review of dental pathology and aging by dental means in nondomestic animals. Parts I and II. Journal of Zoo Animal Medicine 10, 57-65, 8191.

Sauther, M.L., Sussman, R.W. and Cuozzo, F. 2002. Dental and general health in a population of wild ring-tailed lemurs: a life history approach. American Journal of Physical Anthropology 117, 122-132.

Sonne, C., Rigét, F.F., Dietz, R., Wiig, Ø., Kirkegaard, M. and Born, E.W. 2007. Skull pathology in East Greenland and Svalbard polar bears (Ursus maritimus) during 1892 to 2002 in relation to organochlorine pollution. Science of the total environment 372 , 554-561.

Stafne, E.C. and Gibilisco, J.A. 1975. Oral roentgenographic diagnosis. Philadelphia: W.B. Saunders Company. 259pp.

van Valkenburgh, B. 1988. Incidence of tooth breakage among large, predatory mammals. The American Naturalist 131:2, 291-302.

Wenker, C.J., Müller, M., Berger, M., Heiniger, S., Neiger-Aeschbacher, G., Schawalder, P. and Lussi, A. 1998. Dental health status and endodontic treatment of captive brown bears (Ursus arctos ssp.) living in the Bernese Bear Pit. Journal of Veterinary Dentistry 15:1, 27-34.

Wenker, C.J., Stich, H., Müller, M. and Lussi, A. 1999. A retrospective study of dental conditions of captive brown bears (Ursus arctos spp.) compared with free-ranging Alaskan grizzlies (Ursus arctos horribilis). Journal of Zoo and Wildlife Medicine $30: 2,208-221$.

Wiggs, R.B. and Lobprise, H.B. 1997. Veterinary dentistry principles and practice.

Philadelphia: Lippincott Raven. 440-444 pp.

http://img.tfd.com/dorland/thumbs/periodontium.jpg 20080417.

www.buscainmobiliarias.com/se/mapas/dalarna.gif 20080911. 


\section{APPENDIX 1}

$\mathrm{Nr}$ of individual:

Sex: M_ F
Name:

Age:
Place:

Weight (kg):
Date:

Photographed:

Occlusion: Normal:___Other:

Supernumerary teeth: Yes (is drawn)

No

Fractures: Yes (mark with $\mathrm{FC} / \mathrm{FO}$, missing part are colored) No

$\mathrm{pH}$ saliva:

Calculi index $\mathrm{CI}$ :

(index for the whole mouth)
Gingival index GI: (index for the whole mouth)
Absence of teeth: Yes (Mark with a ring, $\mathrm{R}=$ persistent roots)

$$
\text { No___ Tooth wear: }
$$

Caries: Yes No (mark affected tooth with *)

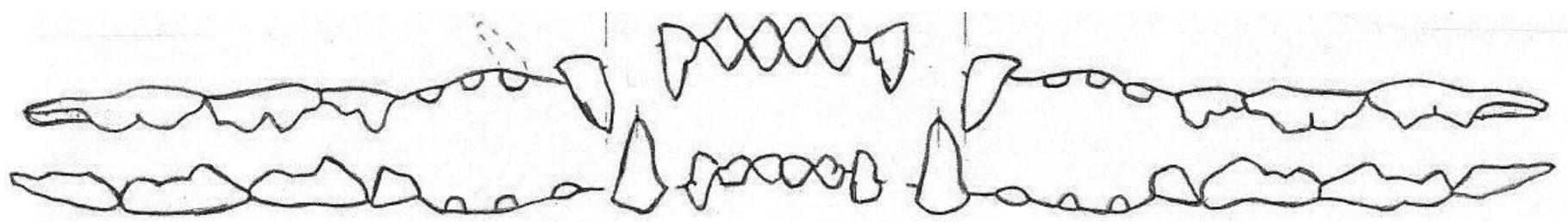

\section{Calculi Index CI} CI O: No calculi is present.

CI 1: Calculi cover less than $50 \%$ of the tooth crowns.

CI 2: Calculi cover more than $50 \%$ but less than $100 \%$ of the tooth crowns.

CI 3: Whole tooth crowns are covered with calculi.

1. Mucous membranes

2. Palpable lymphnodes

3. Heart auscultation

4. Lung auscultation

5. Hydration status

6. Skin and fur

7. Eyes

8. Ears

\section{Normal \\ Not normal \\ Not normal}

Gingival index (GI) GI 0: Normal, no swelling.

GI 1: Less than $50 \%$ of the gingiva has swollen, reddened or rounded margins.

GI 2: More than $50 \%$ of the gingiva has swollen, reddened or rounded margins, and bleeds after passing a periodontal probe gently along the sulcus.

GI 3: GI 2, gingival hyperplasia, ulcer and/or bleeds spontaneously.
Periodontal index (PDI)

PDI 1: GI 1.

PDI 2: GI 1-2, minimal gingival recession, and/or pocket formation in $<25 \%$ of the teeth.

PDI 3: GI 1-3, hyperplasia or pus, gingival recession and pocket formation in $>25 \%$ of the teeth, loose teeth.

PDI 4: GI 2-3, ulcerations and pus, teeth so loose they might fall out.
Periodontal index PDI:

(index for the whole mouth)
Tooth wear TW 1: No wear TW 2: Mild blunting tooth profile TW 3: Moderate wear, TW 4: Teeth worn to th margin of the gingival.

Periodontal pocket depth
Any depth deeper than $4 \mathrm{~mm}$ should be
noted at the correct location on the dental
chart. The depth is noted as a number.
Gingival level
Are marked as a line on the dental chart.
Furcation
Actual tooth are marked with F1-F3.
FI: The alveolar bone has began to be
weakened.
F2: The alveolar bone is missing more
than $50 \%$ trough the furcation.
F3: The alveolar bone is totally missing,
it is a hole from side to side, this could be
felt or seen.
Mobility
The mobility is noted on the dental chart
if one or more teeth are mobile.
$M 1:$ Barely detectable movement.
M2: The tooth is moving, but stays in the
alveolus.
M3: Very loose tooth that can fall out if
touched.
Stomatitis and ulcera
Is drawn and described on the dental
chart.

Periodontal pocket depth

Any depth deeper than $4 \mathrm{~mm}$ should be chart. The depth is noted as a number.

Gingival leve

Furcation

Actual tooth are marked with F1-F3.

F1: The alveolar bone has began to be

T:

than $50 \%$ trough the furcation.

it is a alveolar bone is totaly

The mility is noted on the dental chart

if one or more teeth are mobile.

M1: Barely detectable movement.
M2: The tooth is moving, but stays in the

alveolus.

$M 3$ : Very loose tooth that can fall out if

Stomatitis and ulcera

Is drawn and described on the denta 
